\title{
Assessing the Ethical Behavior of Accounting Accounts Through the Application of the Tri Kaya Parisudha Philosophy on Equity Sensitivity and Ethical Sensitivity
}

\author{
Mertyani Sari Dewi ${ }^{1 *}$, Komang Trisna Sari Dewi², Made Dwi Ferayani ${ }^{3}$ \\ 1,2,3 Sekolah Tinggi Ilmu Ekonomi Satya Dharma, Singaraja, Indonesia
}

\section{ART ICLE INFO}

Article history:

Received July 09, 2021

Revised July 10, 2021

Accepted August 12, 2021

Available online August 25, 2021

Keywords:

Behavior of Accounting Actors, Tri Kaya Parisudha, Equity and Ethical

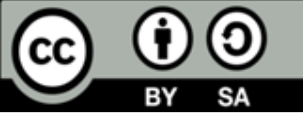

This is an open access article under the CC BY-SA license.

Copyright (@) 2021 by Author. Published by Universitas Pendidikan Ganesha.

\begin{abstract}
A B S T R A C T
The government must pay attention to the ability of its employees because it has accountability that can develop a sound and well-established reporting system. The government must pay attention to the ability of its employees because it has accountability that can develop a sound and well-established reporting system. The purpose of this study was to examine the sensitivity and ethics to the behavior of accounting actors and to examine the philosophy of Tri Kaya Parisudha, which is one of the local variables of the Balinese Hindu genus which can strengthen the effect of sensitivity and sensitivity on ethical behavior. The method used in this research is the Component-based SEM, Partial Least Square (PLS) analysis method. A questionnaire technique was used as a data collection tool to obtain data. Questionnaires will be distributed to 25 OPD Bangli Regency. The test results show empirical evidence that equity sensitivity has a significant positive effect on the behavior of accounting actors. Second, ethical sensitivity has a significant positive effect on the ethical behavior of accounting actors. Third, the philosophy of Tri Kaya Parisudha strengthens the influence of ethical sensitivity on the behavior of ethical accounting actors. Fourth, Tri Kaya Parisudha's philosophy strengthens the influence of ethical sensitivity on the behavior of ethical accounting actors.
\end{abstract}

\section{INTRODUCTION}

Local Government Financial Reports (LKPD) are a form of transparency and accountability in the administration of local government. Accountability and transparency of central and local financial management is a goal in the reform and administration of the public sector. The success of an information system cannot be separated from human behavior (Budiono et al., 2018; Purbasari \& Bawono, 2017). The factor needed is the readiness of human resources for government officials. Ethics and positive attitude of accountants in Indonesia is one of the factors to improve the quality of financial reports (Bangsa, 2019; Budiono et al., 2018). Regional Apparatus Organizations (OPD) which were previously called Regional Apparatus Work Units (SKPD) where this organization as an accounting entity has accounting actors consisting of Treasurers and Financial Administration Officials of Regional Apparatus Work Units (PPK SKPD) (Negara et al., 2017; Puspitaningrum, 2014).

Regional Apparatus Organizations (OPD) as accounting entities have accounting actors consisting of Treasurers and Financial Administration Officials of Regional Apparatus Work Units (PPK SKPD) (Supriatna, 2016; Wiguna \& Putra, 2017). As described in Article 15, PP 58/2005 concerning Regional Financial Management, which is stated as follows: At the suggestion of the Regional Finance Administration Officer (PPKD) appoints a revenue treasurer to carry out treasury duties in the context of implementing the revenue budget at the OPD. The regional head at the suggestion of the PPKD appoints an expenditure treasurer to carry out treasury duties in the context of implementing the budget for the OPD (Astika \& Yasa, 2018; Tumbelaka et al., 2020).

In order to realize effective financial administration, the role of PPK OPD is very vital, in other words, its capabilities and skills in preparing OPD Financial Report documents. With regard to employees, the effectiveness of an organization is highly dependent on individual abilities. The government must pay attention to the ability of its employees because they are required to have accountability that is able to develop a good and well-established reporting system (Smulowitz \& Almandoz, 2021). The phenomenon that can be observed in the development of the public sector today is the increasing demand for the 
implementation of public accountability by public sector organizations such as: central and local governments, government work units, departments and state institutions (Batra, 2021; Sharma et al., 2021).

Regional finance is all regional rights and obligations in the context of administering regional government which can be valued in money, including all forms of wealth related to these rights and obligations (Lv et al., 2021; Wang \& Wang, 2021). The framework of the Regional Revenue and Expenditure Budget. In order to exercise authority over the use of the budget contained in the Budget Implementation Document - Regional Apparatus Work Unit (DPA - OPD), the head of the OPD determines the official who carries out the financial administration function in the SKPD as the OPD financial administration official. The OPD Financial Administration Officer as referred to in paragraph (1) has duties, among others: to prepare the OPD financial report. Then in article 86 paragraph (1) it is stated that the budget user or the proxy of the budget user, the treasurer of receipts or expenditures and the person or entity that receives or controls money or goods or regional assets, is obliged to carry out administration in accordance with the laws and regulations (Astika \& Yasa, 2018).

An important issue in the accounting profession and users is accounting standards. Accounting standards regulated in such a way must be able to provide information to interested parties on financial statements (Harmana, 2021; Karlsson \& Noela, 2021). These accounting standards will change and develop in accordance with the demands and developments of society (Alderman, 2021; Sidhu et al., 2021). The Supreme Audit Agency (BPK) uses accounting standards to examine financial statements. The public accounting profession is often faced with ethical dilemmas from every service offered (Gebreiter, 2021; Ghattas et al., 2021).

The selection of the Bangli Regency Government as the research site in this study considering that the Bangli Regency Government's Financial Statements received different opinions from BPK RI every year. The results of the examination of the Supreme Audit Agency (BPK), the Bangli Regency Government Financial Statements for the 2013 to 2019 fiscal year, obtained an opinion: disclaimer in 2013, a qualified opinion in 2014 and 2015. Bangli Regency received an unqualified opinion on the financial statements local government for the 2016 and 2019 fiscal years. The BPK RI Bali Representative continues to encourage efforts to improve the financial management of the Bangli Regency Government so that it will be better in the future. The most important follow-up steps to improve financial governance are by following up on the opinion given by BPK RI with better performance and optimizing the handling of existing weaknesses. The synergy of all parties is expected to work together to improve what are the weaknesses and factors that determine the quality of LKPD in the Bangli Regency Government as well as what efforts must be made to improve or achieve better opinions, to realize clean and transparent governance and run accountable or accountable government.

Equity sensitivity is one of the internal factors that can affect a person's ethical behavior, equity sensitivity is defined as a personality variable that shows individual reactions when they feel fair and unfair (Bourdage et al., 2018; Rehman et al., 2021). Another internal factor that can influence individual behavior is ethical sensitivity. Individual ethical behavior that is influenced by moral and ethical values cannot be separated from the influence of religion and culture. Ethics and religion have the same goal to lay the basis for moral teachings so that individuals can distinguish between good and bad deeds so that moral teachings in religion and culture are expected to strengthen individual values (Kjeldsen, 2019; Maas, 2019). Tri Kaya Parisudha is part of the philosophy and ethical teachings of Hinduism. Tri Kaya Parisudha consists of three words which have the meaning of tri means three, Kaya means limbs and parisudha means holy, so Tri Kaya Parisudha has three meanings (Dewi et al., 2014; Veronika, 2019). The purified limbs include manacika parisudha which means good thinking, wacika parisudha means good words and kayika parisudha means doing good (Artawan \& Ardiawan, 2018; Somawati \& Made, 2019).

This study uses the variable Tri Kaya Parisudha which is a Balinese Hindu philosophy as a moderating variable where in the concept of Tri Kaya Parisudha there are teachings of moral and ethical values which are expected to strengthen individual values for ethical behavior. The purpose of this research is to examine how the effect of equity sensitivity and ethical sensitivity on the ethical behavior of accounting actors and also to test whether the philosophy of Tri Kaya Parisudha which is one of the local variables of the Balinese Hindu genus is able to strengthen the effect of equity sensitivity and ethical sensitivity on ethical behavior. accounting actors at the Bangli Regency OPD.

\section{METHODS}

The location of this research was conducted at the OPD Bangli Regency. The population in this study are government employees who work in 25 OPD Bangli Regency, which includes 2 secretariats, 1 inspectorate, 5 agencies, 1 office, and 16 offices. The sampling technique used is a non-probability sampling technique, using a saturated sampling technique in which all members of the population are used as samples. While the respondents are the parties used as samples in a study. So that in this study, the 
respondents used were 75 people, consisting of employees who were directly involved in the accounting and financial administration functions of the area consisting of the revenue treasurer, expenditure treasurer and PPK in the Bangli Regency Government. Collecting data in the study using a questionnaire.

\section{RESULTS AND DISCUSSIONS}

\section{Results}

In the outer model validity test, there are two factors that will be observed in the validity test, namely the value of the loading factor (convergent validity) and the value of cross loading (discriminant validity). Convergent validity measures the correlation between question items and constructs in research. The individual reflexive measure is said to be correlated if it is more than 0.7 with the construct to be measured. However, for research in the early stages of developing a measurement scale, a loading factor value of 0.6 is considered sufficient. In the early stages of testing the data to determine the level of accuracy of indicators in explaining exogenous constructs in the model using a loading factor. The loading factor value shows results that have met convergent validity because all loading factors $>0.6$. Thus, it can be concluded that the convergent validity of all constructs is valid. To strengthen the valid statement of the construct of this study, the researcher also used the Average Variance Extracted (AVE) method. A good construct requires that the AVE value must be above 0.50 .

AVE values above 0.5 for all constructs contained in the research model. So it can be concluded that the construct in this study is valid. In this study, the moderating variable is the Tri Kaya Parisudha philosophy, which is measured by five indicators. A construct is said to have high reliability if the Composite Reliability value is above 0.70 and the Cronbachs Alpha value is above 0.60 . It shows that all constructs in this study resulted in Composite Reliability values above 0.70 and Cronbachs Alpha values above 0.60 . It can be concluded that the construct in this study is reliable. In assessing the model with PLS, it begins by looking at the R-square for each dependent latent variable. Based on the data of the coefficient of determination above, it is known that the R-Square value of the Ethical Behavior of Accounting Actors is 0.781 . The R-Square number of 0.781 is equal to $78.1 \%$, which can be explained by four construct variables. The significance of the endogenous indicators can be seen from the T-statistic value. If $t$-value $>t$-table, all indicators can be said to be significant in measuring endogenous constructs. The basis used in testing the hypothesis is the value contained in the output result for inner weight.

\section{Discussion}

Equity sensitivity causes a person to want what he receives in accordance with what he has done (Bourdage et al., 2018; Rehman et al., 2021). An employee who has done his job well must expect to get an appropriate salary for what he has given to his OPD (Maden-Eyiusta \& Alten, 2021; Padmanabhan, 2021). However, if an employee does not get an appropriate salary for what he has done, he will tend to behave unethically because he feels that he is not being treated fairly by the OPD. Therefore, it is important for OPD to provide fair compensation so that employees feel appreciated for what they have done. Employees who are at the point of balance between inputs and outcomes have a higher tendency to behave ethically than employees who do not have equity sensitivity (Jung et al., 2021; López-Cabarcos et al., 2021). The gratitude that each individual has in life can also shape the perception of justice and the balance point they have so that it affects their behavior. The results of this study are in line with attribution theory which explains individual behavior where this theory states the causes and motives of a person's behavior. This is also in line with ethical theory, the difference between right and wrong, good and bad, fair and unfair can be explained in moral concepts (Fan et al., 2021; Singh et al., 2021). The greater the individual's understanding of the moral concepts of fair and unfair, the greater the tendency of individuals to behave ethically.

An employee who has high ethical sensitivity will involve moral values and applicable regulations in every decision making, so that the employee must behave more ethically (Agarwal et al., 2021; Neill \& Bowen, 2021). The ethical sensitivity of each employee must be continuously improved, so it is important for OPD to continue to instill moral values into employees and evaluate if there are ethical violations committed by employees (Byun et al., 2018; Toti et al., 2021). The positive regression coefficient means that the higher the ethical sensitivity of the employee, the higher the ethical behavior shown by the employee in carrying out their duties. Employees who have the ability to recognize the presence of ethical values will use these values as a moral foundation that guides them to behave more ethically (Davidescu et al., 2020; Hidayati et al., 2019). The results of the study are in line with attribution theory which explains that an individual's ability is one of the internal factors that influence his behavior. The theory of ethics is also in line with the results of research where ethics consists of moral principles and standards that encourage individuals to behave ethically. The higher the individual's ability to understand moral and ethical values, the higher his ability to behave ethically (Ariail et al., 2021; Jung et al., 2010). 
This proves that the Tri Kaya Parisudha philosophy strengthens the effect of equity sensitivity on the ethical behavior of accounting actors (Dewi et al., 2014; Somawati \& Made, 2019; Veronika, 2019). The positive regression coefficient means that the increased equity sensitivity accompanied by an understanding of the Tri Kaya Parisudha philosophy will strengthen the effect of equity sensitivity on the ethical behavior of accounting actors. The results of the study are in line with attribution theory which explains that individual behavior is not only influenced by internal factors, it is also influenced by external factors such as the environment, pressure from certain situations or circumstances. The environment such as social conditions, social values, and societal views are external causes that can influence a person's behavior (Priantini, 2020; Selamet, 2017; Suryani et al., 2019). The results of the study are also in line with Kohlberg's theory of cognitive moral development which states that individuals can perceive their environment in stages of development. This theory argues that an employee can build cognitive abilities through actions that are motivated by the environment. Human awareness and perception of justice and ethical principles cannot be separated from religious teachings as in the teachings of tri Kaya parisudha which is an external factor that teaches ethical values to guide individuals to behave ethically (Priantini, 2020; Veronika, 2019).

This proves that the tri Kaya parisudha philosophy strengthens the influence of ethical sensitivity on the Ethical Behavior of Accounting Actors. Positive regression coefficient means that the higher the application of ethical sensitivity accompanied by the tri-kaya parisudha philosophy carried out by employees, the higher the influence of ethical sensitivity on the Ethical Behavior of Accounting Actors. The results of the study are in line with the attribution theory which states that an individual's ability to understand ethical values is influenced by external factors such as religious teachings. Tri Kaya Parisudha is one of the teachings of morality or ethics in Hinduism that affects the individual's ability to understand moral and ethical values as a guide to behavior (Dewi et al., 2014; Veronika, 2019). This is in line with the theory of cognitive moral development which states that moral reasoning is seen as a structure not content. If moral reasoning is seen as content, then something is said to be good or bad, depending on the particular socio-cultural environment so that its nature will be relative. But if moral reasoning is seen as a structure, then what is good and bad is related to the principle of morality, so moral reasoning is universal. The limitation of this research is that this research uses a questionnaire distribution method so that the conclusions are only based on the data collected in writing on the questionnaire sheet. Therefore, further research is carried out using the interview method so that the questions given are actually answered by the parties involved in the preparation of financial statements.

\section{CONCLUSION}

The conclusion in this study is that equity sensitivity has a significant positive effect on the ethical behavior of accounting actors, ethical sensitivity has a significant positive effect on the ethical behavior of accounting actors, the Tri Kaya Parisudha philosophy strengthens the influence of ethical sensitivity on the ethical behavior of accounting practitioners and the Tri Kaya Parisudha philosophy strengthens the ethical sensitivity effect on ethical behavior of accounting practitioners.

\section{REFERENCES}

Agarwal, U. A., Gupta, M., \& Cooke, F. L. (2021). Knowledge hide and seek: Role of ethical leadership, selfenhancement and job-involvement. Journal of Business Research. https://doi.org/10.1016/j.jbusres.2021.11.074.

Alderman, J. (2021). Women in the smart machine age: Addressing emerging risks of an increased gender gap in the accounting profession. Journal of Accounting Education, 55. https: //doi.org/10.1016/j.jaccedu.2021.100715.

Ariail, D. L., Khayati, A., \& Shawver, T. (2021). Perceptions by employed accounting students of ethical leadership and political skill: Evidence for including political skill in ethics pedagogy. Journal of Accounting Education, 55. https://doi.org/10.1016/j.jaccedu.2021.100716.

Artawan, K. N., \& Ardiawan, I. K. N. (2018). Pembelajaran quantum Teaching berbasis Tri Kaya Parisudha. Edudikara: Jurnal Pendidikan Dan Pembelajaran, 3(2), 201-212. https://doi.org/10.32585/edudikara.v3i2.100.

Astika, I. B. P., \& Yasa, G. W. (2018). Kemampuan Komitmen Organisasi Memoderasi Kompetensi Pejabat Penatausahaan Keuangan dan SPI Pada Kualitas Laporan Keuangan Kota Denpasar. E-Jurnal Akuntansi, 22(1). https://doi.org/10.24843/EJA.2018.v22.i01.p12.

Bangsa, I. N. (2019). The Effect of Internal Control Systems, Accounting Systems on the Quality of Financial Statements Moderated by Organizational Commitments. Accounting Analysis Journal, 7(2). 
https://doi.org/10.15294/aaj.v7i2.20616.

Batra, R. (2021). A thematic analysis to identify barriers, gaps, and challenges for the implementation of public-private-partnerships in housing. Habitat International, 118. https://doi.org/10.1016/j.habitatint.2021.102454.

Bourdage, J. S., Goupal, A., Neilson, T., Lukacik, E.-R., \& Lee, N. (2018). Personality, equity sensitivity, and discretionary workplace behavior. Personality and Individual Differences, 120. https://doi.org/10.1016/j.paid.2017.08.018.

Budiono, V. S., Muchlis, M., \& Masri, I. (2018). Analisis Pengaruh Pendidikan Dan Pelatihan, Pengalaman Kerja Serta Pemanfaatan Teknologi Informasi Terhadap Kualitas Laporan Keuangan Pemerintah Daerah (Studi Kasus Pada Pemerintah Kota Depok). Jurnal Ilmiah Wahana Akutansi, 13(2). https://doi.org/10.21009/wahana.13.022.

Byun, G., Karau, S. J., Dai, Y., \& Lee, S. (2018). A three-level examination of the cascading effects of ethical leadership on employee outcomes: A moderated mediation analysis. Journal of Business Research, 88. https://doi.org/10.1016/j.jbusres.2018.03.004.

Davidescu, A. A., Apostu, S.-A., Paul, A., \& Casuneanu, I. (2020). Work Flexibility, Job Satisfaction, and Job Performance among Romanian Employees-Implications for Sustainable Human Resource Management. Sustainability, 12(15), 6086. https://doi.org/10.3390/su12156086.

Dewi, N. K. C., Sedanayasa, G., \& Sulastri, M. (2014). Pengaruh Moidel Pembelajaran Numbered Head Together Berlandasakan Tri Kaya Parisudha Terhadap Hasil Belajar IPA Siswa Kelas V. Mimbar Pgsd Universitas Pendidikan Ganesha, 2(1). https://doi.org/10.23887/jjpgsd.v2i1.4144.

Fan, X., Li, J., Mao, Z. (Eddie), \& Lu, Z. (2021). Can ethical leadership inspire employee loyalty in hotels in China? -From the perspective of the social exchange theory. Journal of Hospitality and Tourism Management, 49. https://doi.org/10.1016/j.jhtm.2021.11.006.

Gebreiter, F. (2021). A profession in peril? University corporatization, performance measurement and the sustainability of accounting academia. Critical Perspectives on Accounting. https://doi.org/10.1016/j.cpa.2021.102292.

Ghattas, P., Soobaroyen, T., \& Marnet, O. (2021). Charting the development of the Egyptian accounting profession (1946-2016): An analysis of the State-Profession dynamics. Critical Perspectives on Accounting, 78. https://doi.org/10.1016/j.cpa.2020.102159.

Harmana, I. M. D. (2021). Pengaruh Pengalaman, Idealisme Dan Komitmen Profesional Pada Pembuatan Keputusan Etis Konsultan Pajak. Accounting Profession Journal, 3(1). https: //doi.org/10.35593/apaji.v3i1.22.

Hidayati, S. K., Perizade, B., \& Widiyanti, M. (2019). Effect Of Work Discipline And Work Environment To Performance Of Employees. International Journal of Scientific and Research Publications (IJSRP), 9(12). https://doi.org/10.29322/ijsrp.9.12.2019.p9643.

Jung, H. S., Jung, Y. S., \& Yoon, H. H. (2021). COVID-19: The effects of job insecurity on the job engagement and turnover intent of deluxe hotel employees and the moderating role of generational characteristics. International Journal of Hospitality Management, 9. https: //doi.org/10.1016/j.ijhm.2020.102703.

Jung, H. S., Namkung, Y., \& Yoon, H. H. (2010). The effects of employees' business ethical value on personorganization fit and turnover intent in the foodservice industryNo Title. International Journal of Hospitality Management, 29(3). https://doi.org/10.1016/j.ijhm.2009.08.005.

Karlsson, P., \& Noela, M. (2021). Beliefs influencing students' career choices in Sweden and reasons for not choosing the accounting profession. Journal of Accounting Education. https: //doi.org/10.1016/j.jaccedu.2021.100756.

Kjeldsen, K. (2019). A study-of-religion(S)-based religion education: Skills, knowledge, and aims. Center for Educational Policy Studies Journal, 9(4), 11-29. https://doi.org/10.26529/cepsj.678.

López-Cabarcos, M. Á., Vázquez-Rodríguez, P., \& Quiñoá-Piñeiro, L. M. (2021). An approach to employees' job performance through work environmental variables and leadership behaviours. Journal of Business Research. https://doi.org/10.1016/j.jbusres.2021.11.006.

Lv, C., Bian, B., Lee, C.-C., \& He, Z. (2021). Regional gap and the trend of green finance development in China. Energy Economics, 105. https://doi.org/10.1016/j.eneco.2021.105476.

Maas, P. H. (2019). Curriculum Development, Islamic Religious Education, Islamic Elementary School AL Azhar. Atthulab: Islamic Religion Teaching and Learning Journal, 4(1). https://doi.org/10.15575/ath.v4i1.2850.

Maden-Eyiusta, C., \& Alten, O. (2021). Expansion-oriented job crafting and employee performance: A selfempowerment perspective. European Management Journal. https://doi.org/10.1016/j.emj.2021.10.012.

Negara, P. K., Handajani, L., \& Effendy, L. (2017). Studi Kasus Fenomena Tingkat Serapan Anggaran pada 
Satuan Kerja Perangkat Daerah. Journal of Accounting and Investment, 1(2). https://doi.org/10.18196/jai.190193.

Neill, M. S., \& Bowen, S. A. (2021). Employee perceptions of ethical listening in U.S. organizations. Public Relations Review, 47(5). https://doi.org/10.1016/j.pubrev.2021.102123.

Padmanabhan, S. (2021). The impact of locus of control on workplace stress and job satisfaction: A pilot study on private-sector employees. Current Research in Behavioral Sciences, 2. https://doi.org/10.1016/j.crbeha.2021.100026.

Priantini, D. A. (2020). The Development Of Teaching Video Media Based On Tri Kaya Parisudha In Educational Psychology Courses. Journal of Education Technology, 4(4). https://doi.org/10.23887/jet.v4i4.29608.

Purbasari, H., \& Bawono, A. D. B. (2017). Pengaruh Desentralisasi Fiskal, Sistem Pengendalian Internal Dan Kinerja Pemerintah Daerah Terhadap Akuntabilitas Laporan Keuangan. Riset Akutansi Dan Keuangan Indonesia, 2(2). https://doi.org/10.23917/reaksi.v2i2.4884.

Puspitaningrum, W. P. (2014). Pendeteksian Kecurangan Laporan Keuangan Pemerintah Daerah di Indonesia (Studi Kasus pada Pemerintah Kota Surakarta). Jurnal Akuntansi Dan Bisnis, 14(1). https://doi.org/10.20961/jab.v14i1.153.

Rehman, M. U., Sensoy, A., Eraslan, V., Shahzad, S. J. H., \& Vo, X. V. (2021). Sensitivity of US equity returns to economic policy uncertainty and investor sentiments. The North American Journal of Economics and Finance, 57. https://doi.org/10.1016/j.najef.2021.101392.

Selamet, N. W. (2017). Pengaruh Model Pembelajaran Numbered Head Together Berbasis Tri Kaya Parisudha Terhadap Hasil Belajar IPS Siswa Kelas IV". E- Journal PGSD Universitas Pendidikan Ganesha. MIMBAR PGSD Undiksha, 5(2), 1-11. https://doi.org/10.23887/jjpgsd.v5i2.10768.

Sharma, M., Luthra, S., Joshi, S., \& Kumar, A. (2021). Implementing challenges of artificial intelligence: Evidence from public manufacturing sector of an emerging economy. Government Information Quarterly. https://doi.org/10.1016/j.giq.2021.101624.

Sidhu, J., Carnegie, G. D., \& West, B. (2021). Australia's divided accounting profession: The 1969 merger attempt and its legacy. The British Accounting Review, 53(3). https://doi.org/10.1016/j.bar.2021.100975.

Singh, G., Sharma, S., Sharma, R., \& Dwivedi, Y. K. (2021). Investigating environmental sustainability in small family-owned businesses: Integration of religiosity, ethical judgment, and theory of planned behavior. Technological Forecasting and Social Change, 173. https://doi.org/10.1016/j.techfore.2021.121094.

Smulowitz, S. J., \& Almandoz, J. ("John"). (2021). Reprint of "Predicting employee wrongdoing: The complementary effect of CEO option pay and the pay gap." Organizational Behavior and Human Decision Processes, 166. https://doi.org/10.1016/j.obhdp.2021.02.007.

Somawati, A. V., \& Made, Y. A. D. N. (2019). Implementasi Ajaran Tri Kaya Parisudha Dalam Membangun Karakter Generasi Muda Hindu Di Era Digital. Jurnal Pasupati, 6(1). https://doi.org/10.37428/pspt.v6i1.135.

Supriatna, N. (2016). Pengaruh Implementasi Sistem Pengendalian Internal Terhadap Kinerja Instansi Pemerintah (Studi Kasus Pada Organisasi Perangkat Daerah Pemerintah Kota Bandung). Jurnal Riset Akuntansi Dan Keuangan, 4(1). https://doi.org/10.17509/jrak.v4i1.7716.

Suryani, N. K., Renda, N. T., \& Wibawa, I. M. C. (2019). Pengaruh Pendekatan Saintifik Berorientasi Tri Kaya Parisudha Terhadap Penguasaan Konsep Ipa Dan Keterampilan Proses Sains Siswa Kelas V Sd Di Gugus Vii Kecamatan Sukasada Kabupaten Buleleng Tahun Pelajaran 2018/2019. Journal of Education Technology. https://doi.org/10.23887/jet.v3i1.17962.

Toti, J.-F., Diallo, M. F., \& Huaman-Ramirez, R. (2021). Ethical sensitivity in consumers' decision-making: The mediating and moderating role of internal locus of control. Journal of Business Research, 131. https://doi.org/10.1016/j.jbusres.2021.03.045.

Tumbelaka, H. I. A., Elim, I., \& Kalalo, M. (2020). Analisis pengelolaan dana desa studi kasus di Kecamatan Tatapaan Kabupaten Minahasa Selatan. Indonesia Accounting Journal, 2(2). https://doi.org/10.32400/iaj.27703.

Veronika, A. (2019). Implementasi Ajaran Tri Kaya Parisudha Dalam Membangun Karakter Generasi Muda Hindu Di Era Digital. Jurnal PASUPATI, 6(2). https://doi.org/10.37428/pspt.v6i1.135.

Wang, X., \& Wang, Q. (2021). Research on the impact of green finance on the upgrading of China's regional industrial structure from the perspective of sustainable development. Resources Policy, 74. https://doi.org/10.1016/j.resourpol.2021.102436.

Wiguna, M., \& Putra, A. A. (2017). Analisis Faktor-Faktor Yang Mempengaruhi Penerapan Good Government Governance (Studi Empiris Pada Pemerintah Kabupaten Indragiri Hilir). Jurnal Akuntansi Keuangan Dan Bisnis, 10(2). https://jurnal.pcr.ac.id/index.php/jakb/article/view/1392. 